\title{
Satisfaction, stress and burnout of nurse managers and care nurses in Primary Health Care*
}

\author{
Satisfação, estresse e esgotamento profissional de enfermeiros \\ gestores e assistencialistas da Atenção Primária à Saúde \\ Satisfacción, estrés y agotamiento profesional de enfermeros gestores \\ y enfermeros de cuidado en Atención Primaria de Salud
}

How to cite this article:

Aires Garcia GP, Marziale MHP. Satisfaction, stress and burnout of nurse managers and care nurses in Primary Health Care. Rev Esc Enferm USP. 2021;55:e03675. doi: https://doi.org/10.1590/S1980-220X2019021503675

\author{
Gracielle Pereira Aires Garcia ${ }^{1}$ \\ Maria Helena Palucci Marziale ${ }^{2}$ \\ * Extracted from the dissertation: "Fatores \\ estressores, de esgotamento profissional \\ e satisfação no trabalho de enfermeiros \\ atuantes na Atenção Primária à Saúde”, \\ Escola de Enfermagem de Ribeirão Preto, \\ Universidade de São Paulo, 2018. \\ 1 Universidade de São Paulo, Escola de \\ Enfermagem de Ribeirão Preto, Programa \\ de Pós-Graduação em Enfermagem \\ Fundamental, Ribeirão Preto, SP, Brazil. \\ 2 Universidade de São Paulo, Escola \\ de Enfermagem de Ribeirão Preto, \\ Departamento de Enfermagem Geral e \\ Especializada, Ribeirão Preto, SP, Brazil.
}

Corresponding author:

Gracielle Pereira Aires Garcia

Av. João XXIII, 380, Apto 802, Ed. Dona

Samira, Bairro Mãe de Deus

CEP 75702-900 - Catalão, GO, Brazil

gracielleaires@gmail.com

\begin{abstract}
Objective: To correlate the indicators of job satisfaction, factors of occupational stress and professional exhaustion among nurse managers and care nurses in Primary Health Care. Method: Descriptive, exploratory field study conducted in 45 units of Primary Health Care in Brazil. The following instruments were used for data collection: Sociodemographic Questionnaire, Work Stress Scale, Burnout Characterization Scale and the Job Satisfaction Questionnaire - S20/23. Results: Participation of 122 nurses (47.5\% managers; $62.5 \%$ care), $32 \%$ had considerable stress levels, indicators of emotional exhaustion, dehumanization and disappointment at work in moderate to high levels. The indicator of satisfaction with the physical work environment did not show significance with variables of professional exhaustion, while satisfaction with hierarchical relations and intrinsic job satisfaction are strongly correlated. Conclusion: There is an association between organizational problems and working conditions that hinder nurses' work. Regardless of the position, job satisfaction is inversely proportional to burnout.
\end{abstract}

\section{DESCRIPTORS}

Primary Care Nursing; Job Satisfaction; Stress, Psychological; Burnout Professional; Occupational Health. 


\section{INTRODUCTION}

In nursing work, the assessment of the health needs of professionals has been the object of analysis and debate, together with the relationship between work and the environment and the inadequate working conditions offered to these professionals.

In Primary Health Care (PHC) services in Brazil, also known as Basic Health Care or simply Primary Care (PC), nurses face family and social conflicts in poor communities and, in Health Promotion, they seek to meet the challenges of the Unified Health System (Brazilian SUS). These workers provide comprehensive care to users and families and, when indicated or necessary, at home and in community spaces. The services provided by PC professionals are a SUS priority, given the focus on preventive and health promotion actions that interfere in the health-disease process and benefit the control of the worsening of Chronic Noncommunicable Diseases $^{(1-2)}$.

In 2006, with Ordinance No. 648, the National Primary Care Policy emerged to define the strategies for operationalization and consolidation of Primary Care in Brazil, since discussions and trends in the health area were aimed at improving management models ${ }^{(3)}$. Subsequently, it was updated by Ordinance No. 2488 of 21 October, $2011^{(1)}$ and reformulated by Ordinance No. 2436 of 21 September, 2017 to revise the guidelines for the organization of $\mathrm{PHC}^{(4)}$.

Primary services are in the consolidation phase and form the basis for modern health systems, but there are challenges for their proper operationalization. In this scenario, the role of nurses is increasingly significant and important ${ }^{(5)}$. The National Health Service (NHS) in England is an example of a health system in which the skills and duties of nurses in direct primary care to patients were expanded as a clinical function guided by the use of protocols and management. However, in the context of PHC, English nurses feel pressured by the government and employers' policies to expand their functions as a result of the eminent exhaustion caused by work overload ${ }^{(6)}$.

Nurses feel professionally limited because of economic, political and technological factors and others, such as poor working conditions and lack of autonomy, which restrict the achievement of their goals and make them feel overwhelmed, with their compromised physical and mental wellbeing, often resulting in illness due to the work performed ${ }^{(2,7-9)}$.

Likewise, the work situation experienced by nurses can also cause their dissatisfaction and redefinition of the value and usefulness of work, as occurred in Barcelona. Coping with an economic crisis resulted in a public deficit for the health budget and led to professional downsizing and consequent increase in work overload and psychosocial risks ${ }^{(10)}$.

Job satisfaction is an important condition for maintaining human physical and mental health, is related to higher productivity ${ }^{(11-12)}$ and is a fundamental aspect to make workers more efficient and less likely to fall ill ${ }^{(5)}$.

Job dissatisfaction and satisfaction are a dialectical movement and both depend on the perceived relationship between what one wants from the job and what the job offers or how it involves the worker ${ }^{(13)}$. There is a need for actions directed to the improvement of job satisfaction levels, prevention of occupational stress and manifestations of professional exhaustion in PHC nurses caused by demands of specific tasks and skills of nursing care to the population ${ }^{(8)}$.

The scientific knowledge gaps on this topic found in the literature require a critical reflection on the current configuration of $\mathrm{PHC}$ work from the perspective of nurses, who are protagonists in the proper functioning of this system. The investigated constructs of job satisfaction and stress of nurses are configured as psychosocial indicators for the occurrence of professional exhaustion. They must be identified, given their direct impact on the intervention capacity of actions to prevent mental health problems at work.

This study sought to answer the following research questions: What are the indicators of job satisfaction, stressors and exhaustion factors that nurses identify at work in PHC units? Are there differences between the perception of nurse managers and care nurses? Therefore, the aim of this investigation was to correlate indicators of job dissatisfaction, factors of occupational stress and professional exhaustion among nurse managers and care nurses working in PHC units.

\section{METHOD}

\section{TYPE OF STUDY}

Descriptive, exploratory field study that proposed the investigation of associations and correlations, cross-sectional with data collection at a given time, and quantitative analysis of data.

\section{Population}

The population was composed of 130 nurses, of which 122 nurses working in $45 \mathrm{PHC}$ units or at the Health Secretariat of the city of Ribeirão Preto - São Paulo state agreed to participate in the study.

\section{Data collection}

Data were collected between June and August 2017. A questionnaire prepared by the authors themselves was used in data collection to obtain sociodemographic data and characterize the participants. The instrument was structured with the following data: age, sex, marital status, children, time of profession, place of work (management/care), workload, working time in PHC, employment contract, presence of another job bond, professional qualification (specialization/ Master or $\mathrm{PhD}$ postgraduate studies).

Three other instruments were applied: Work Stress Scale (WSS); Burnout Characterization Scale (BCS); and Job Satisfaction Questionnaire (S20/23).

The WSS is a single factor scale composed of 23 items on a Likert-type scale to indicate the degree of agreement with the opinion expressed by the statement, in which the value 1 - Strongly Disagree, 2 - Disagree, 3 - Partially Agree, 4 Agree and 5 - Totally agree ${ }^{(14)}$. The Cronbach's Alpha value 
for this population was $\alpha=0.93$, thus ensuring reliability and internal consistency.

The BCS was developed and validated for use in Brazil. It consists of 35 statements about feelings and attitudes towards work with a three-factor structure: Factor I - Emotional Exhaustion (twelve items); Factor II - Dehumanization (ten items); and, Factor III - Disappointment at Work (thirteen items). The Likert scale is also used with $1-$ Never, $2-$ Rarely, 3 - Sometimes, 4 - Often and 5 - Always ${ }^{(15)}$. The BCS presents three items (6 - I think things I do in my work are worthwhile; 23 - I feel identified with my work; 35 - I feel full of energy to work) with positive semantics in relation to others, which are negative and could even be excluded. However, one decided to invert the applied values to transform them into an indicator of the syndrome belonging to Factor III. In this study, the instrument showed levels of internal consistency with high values in its factors (Emotional Exhaustion $\alpha=0.94$; Dehumanization $\alpha=0.83$; and, Disappointment at Work $\alpha=0.90)$.

The Job Satisfaction Questionnaire (S20/23) is a Brazilian adaptation of the short version of Questionnaire $\mathrm{S} 4 / 82^{(16)}$. It has 23 items, of which only three factors found in relation to the original scale: Factor I - Satisfaction with Hierarchical Relations (SHR), which maintained the items of satisfaction with supervision and satisfaction with participation and added two items of satisfaction with the benefits and policies of the organization, totaling eleven items; Factor II - Satisfaction with the Physical Work Environment (SPWE) maintained the five items; Factor III - Intrinsic Job Satisfaction (IJS) maintained all items of the original version that has the same name and added three items of satisfaction with the benefits and policies of the organization, totaling seven items. In the responses, a Likert scale was also used, 1 - Totally Dissatisfied, 2 - Partially Dissatisfied, 3 Neutral, 4 - Partially Satisfied and 5 - Totally Satisfied. For this study, the instrument is valid and reliable with the 23 complete items and Alfa Cronbach values in the respective factors (SHR $\alpha=0.90$; SPWE $\alpha=0.87$; IJS $\alpha=0.75$ ).

\section{ANALYSIS AND TREATMENT OF DATA}

The Shapiro-Wilk test was used to compare the groups of nurse managers and care nurses by checking the normality of variables. With variables that showed normality, the Student's t test was used (BCS - Dehumanization; Job Satisfaction Questionnaire (S20/23) - SHR), and for variables that did not show normality (WSS; BCS - emotional exhaustion and disappointment at work; Job Satisfaction Questionnaire (S20/23) - SPWE and IJS) the MannWhitney $U$ test was applied. To relate the scores obtained from the Work Satisfaction Questionnaire (S20/23) and the BCS and WSS scales for both groups, the Spearman's Correlation Coefficient was used. For statistical analysis, the significance level $\alpha=0.05$ was adopted.

\section{ETHICAL ASPECTS}

The normalization of Resolution no. 466/2012 of the National Health Council, which regulates research with human beings was followed in the development of this study. It was approved by the Research Ethics Committee of the Ribeirão Preto School of Nursing under protocol number 65353317.8.0000.5393, on June 1, 2017.

Participants were invited (individually) to participate at their own workplace by the researcher, who requested the signature of the Informed Consent form for acceptance and informed participants about the study objectives, the format of the questionnaires and the guarantee of all ethical aspects.

\section{RESULTS}

Participated in the study 122 nurses, aged between 25 and 66 years old. The mean age was 45.2 years ( $\mathrm{SD} \pm 9.8), 47$ (38.5\%) aged 50-59 years, 115 (94.3\%) female, 72 (59\%) were married and $81(66.4 \%)$ had children. Regarding working time, 52 (42.6\%) nurses had more than 25 years of profession and $26(21.3 \%)$ nurses had more than 25 years of work in PHC.

Of the participants, 58 (47.5\%) nurses work in management and $64(52.5 \%)$ in care. The weekly workload of nurses varied between 20 and 40 hours; 37 (30.3\%) nurses worked 20 hours, four (3.3\%) worked 30 hours, 79 (64.8\%) worked 40 hours and one $(0.8 \%)$ worked 36 hours a week.

As for the work regime, 105 (86.1\%) nurses were hired as civil servants under the municipal statutory regime and 17 (13.9\%) had work contracts governed by the Consolidation of Labor Laws (Consolidação das Leis do Trabalbo - CLT). When asked about other employment bonds, 23 (18.9\%) nurses said they had another job.

Regarding the characterization of nurses' perception expressed by the responses to the instruments used, according to the WSS, 39 (32\%) nurses presented considerable stress levels, with indicators above or equal to 2.5 and interval variance between 1.0 and 4.8 , mean of $2.2(\mathrm{SD} \pm 0.7)$. Despite being a single factor scale, the WSS items with greater increased perception of stress were the lack of organizational information, insufficient time due to work overload, lack of clarity in the distribution of tasks and ineffectiveness in interpersonal communication.

For the characterization of Burnout using the BCS, the scores of each factor composing the scale, and the 25, 50 and 75 percentiles of the distribution with the standard reference response of the investigated population were calculated to establish the cutoff points for each category: light, moderate and high, according to results presented in Table 1.

In the emotional exhaustion factor, the light level obtained 42 (34.4\%), moderate 46 (37.7\%) and high 34 (27.9\%). As for dehumanization, the light level was 40 (32.8\%), moderate 51 (41.8) and high 31 (25.4\%). Regarding disappointment at work, the light level was 33 (27\%), moderate 58 (47.5\%) and high 31 (25.4\%). There was significance at the moderate level for the three factors which showed higher rates of occurrence, with emphasis on disappointment at work. 
Table 1 - Description of the interval obtained, median, mean, standard deviation (SD) and percentiles of responses of nurses in PHC in the factors of the Burnout Characterization Scale - Ribeirão Preto, SP, Brazil, 2017.

\begin{tabular}{|c|c|c|c|c|c|c|}
\hline \multirow{2}{*}{ BCS factors } & \multirow{2}{*}{ Interval obtained } & \multirow{2}{*}{ Median } & \multirow{2}{*}{ Mean (SD) } & \multicolumn{3}{|c|}{ Percentiles } \\
\hline & & & & $\mathbf{P}_{25}$ & $\mathbf{P}_{50}$ & $\mathbf{P}_{75}$ \\
\hline Emotional exhaustion (12 items) & $1.1-3.8$ & 2.3 & $2.3(0.7)$ & 1.8 & 2.3 & 3.0 \\
\hline Dehumanization (10 items) & $1.1-2.9$ & 1.7 & $1.7(0.4)$ & 1.5 & 1.7 & 2.0 \\
\hline Disappointment at work (13 items) & $1.1-3.6$ & 1.7 & $1.7(0.5)$ & 1.3 & 1.7 & 2.1 \\
\hline
\end{tabular}

Note: $(n=122)$.

The Job Satisfaction Questionnaire (S20/23) shows the degree of satisfaction in its various aspects (SHR, SPWE and IJS). The mean values are higher compared to those obtained through the other instruments used, above 3 for all factors, of which the lowest, 3.4 ( $\mathrm{SD} \pm 0.8$ ), was for $\mathrm{SHR}$, followed by 3.5 $(\mathrm{SD} \pm 1.0)$ for $\mathrm{SPWE}$ and $3.8(\mathrm{SD} \pm 0.6)$ for IJS. However, when analyzing the obtained interval, responses varied between 1.0
- 5.0, that is, either one is very satisfied or totally dissatisfied. If the participant's answer is 3 , it shows indifference (neutral), that is, one is neither dissatisfied nor satisfied.

For the statistical analyzes, nurse managers and care nurses were compared according to data obtained from the instruments used, presenting the p-value, the Student's $t$ test or the Mann-Whitney U test in Table 2.

Table 2 - Comparison between the groups of nurses in PHC according to the role performed and scores of the Work Stress Scale, Burnout Characterization Scale and Job Satisfaction Questionnaire (S20/23) - Ribeirão Preto, SP, Brazil, 2017.

\begin{tabular}{|c|c|c|c|}
\hline Variables & $\begin{array}{l}\text { Nurse managers } \\
\quad(n=58)\end{array}$ & Care nurses $(n=64)$ & $P$ value \\
\hline Work Stress Scale (total mean) & & & $0.306^{* *}$ \\
\hline Interval obtained & $1.1-4.8$ & $1.0-4.1$ & \\
\hline Median & 2.1 & 2.2 & \\
\hline Mean (SD) & $2.2(0.7)$ & $2.3(0.6)$ & \\
\hline Burnout Characterization Scale (emotional exhaustion) & & & $0.162^{* *}$ \\
\hline Interval obtained & $1.1-3.6$ & $1.1-3.8$ & \\
\hline Median & 2.5 & 2.1 & \\
\hline Mean (SD) & $2.4(0.7)$ & $2.3(0.7)$ & \\
\hline Burnout Characterization Scale (dehumanization) & & & $0.019 *$ \\
\hline Interval obtained & $1.0-2.6$ & $1.0-2.9$ & \\
\hline Median & 1.6 & 1.8 & \\
\hline Mean (SD) & $1.6(0.3)$ & $1.8(0.4)$ & \\
\hline Burnout Characterization Scale (disappointment at work) & & & $0.555^{* *}$ \\
\hline Interval obtained & $1.1-3.0$ & $1.0-3.6$ & \\
\hline Median & 1.6 & 1.7 & \\
\hline Mean (SD) & $1.7(0.5)$ & $1.7(0.6)$ & \\
\hline Work Satisfaction Questionnaire (satisfaction with hierarchical relations) & & & $0.964^{*}$ \\
\hline Interval obtained & $1.3-4.6$ & $1.7-5.0$ & \\
\hline Median & 3.4 & 3.4 & \\
\hline Mean (SD) & $3.4(0.72)$ & $3.4(0.84)$ & \\
\hline $\begin{array}{l}\text { Work Satisfaction Questionnaire } \\
\text { (satisfaction with the physical work environment) }\end{array}$ & & & $0.341^{* *}$ \\
\hline Interval obtained & $1.0-5.0$ & $1.0-5.0$ & \\
\hline Median & 3.6 & 3.6 & \\
\hline Mean (SD) & $3.6(1.0)$ & $3.4(1.0)$ & \\
\hline Work Satisfaction Questionnaire (intrinsic job satisfaction) & & & $0.012^{* *}$ \\
\hline Interval obtained & $2.7-4.7$ & $1.6-5.0$ & \\
\hline Median & 4.0 & 3.8 & \\
\hline Mean (SD) & $4.0(0.5)$ & $3.7(0.6)$ & \\
\hline
\end{tabular}

*Student's t test; **Mann-Whitney $\mathrm{U}$ test

Note: $(n=122)$. 
After applying the statistical tests, there was significance between the studied groups only in dehumanization ( $p=0.019)$ of the BCS and IJS ( $p=0.012)$ of the Job Satisfaction Questionnaire (S20/23).

Regarding the correlation for both nurse managers and care nurses, the SPWE did not present any significance with the variables of professional exhaustion, although stress, SHR and IJS were strongly correlated. As far as nurse managers are concerned, dehumanization was correlated with SHR and IJS, unlike care nurses, in which there was no correlation. Intrinsic Job Satisfaction was strongly correlated with Burnout variables, just as it is inversely proportional.

The Spearman's correlation was also performed between the dependent and independent variables of the groups evaluated. These results are shown in Table 3 .

Table 3 - Spearman's correlation between the dependent and independent variables of the groups of nurse managers and care nurses in PHC - Ribeirão Preto, SP, Brazil, 2017.

\begin{tabular}{|c|c|c|c|c|c|c|c|c|c|}
\hline \multirow{2}{*}{$\begin{array}{l}\text { Dependent } \\
\text { Variables }\end{array}$} & & \multicolumn{4}{|c|}{$\begin{array}{l}\text { Independent variables Nurse managers } \\
\qquad(\mathrm{n}=58)\end{array}$} & \multicolumn{4}{|c|}{$\begin{array}{l}\text { Independent variables } \\
\text { Care nurses }(n=64)\end{array}$} \\
\hline & & Stress & $\mathrm{SHR}^{*}$ & SPWE ** & IJS ** & Stress & SHR & SPWE & IJS \\
\hline \multirow{2}{*}{ Emotional exhaustion } & Coefficient & 0.414 & -0.262 & -0.230 & -0.368 & 0.479 & -0.366 & -0.121 & -0.408 \\
\hline & $P$ value & 0.001 & 0.047 & 0.083 & 0.005 & 0.000 & 0.003 & 0.340 & 0.001 \\
\hline \multirow{2}{*}{ Dehumanization } & Coefficient & 0.239 & -0.305 & -0.181 & -0.341 & 0.231 & -0.048 & -0.088 & -0.195 \\
\hline & $P$ value & 0.071 & 0.020 & 0.173 & 0.009 & 0.066 & 0.706 & 0.489 & 0.123 \\
\hline \multirow{2}{*}{$\begin{array}{l}\text { Disappointment at } \\
\text { work }\end{array}$} & Coefficient & 0.351 & -0.237 & -0.259 & -0.458 & 0.352 & -0.387 & -0.147 & -0.447 \\
\hline & $P$ value & 0.007 & 0.073 & 0.050 & 0.000 & 0.004 & 0.002 & 0.246 & 0.000 \\
\hline
\end{tabular}

*Satisfaction with Hierarchical Relations; **Satisfaction with the Physical Work Environment; *** Intrinsic Job Satisfaction.

Note: nurse managers $(n=58)$ and care nurses $(n=64)$.

For both nurse managers and care nurses, the correlation was significant $(p<0.05)$ between emotional exhaustion and stress $(p=0.001$ and $p=0.000)$, SHR $(p=0.047$ and $p=0.003$ ) and IJS ( $p=0.005$ and $p=0.001)$. However, in nurse managers, in dehumanization, the correlation was significant with SHR ( $\mathrm{p}=0.020)$ and IJS $(\mathrm{p}=0.009)$, while in disappointment at work, it was significant only with stress $(\mathrm{p}=0.007)$ and IJS ( $\mathrm{p}=0.000)$. Unlike care nurses, as it showed statistical importance between disappointment at work with stress $(\mathrm{p}=0.004)$, SHR $(\mathrm{p}=0.002)$ and IJS $(\mathrm{p}=0.000)$, but the same did not occur with dehumanization. There was no correlation with SPWE in any of the groups and IJS was strongly correlated with Burnout.

Regarding the correlation coefficient, stress is not inversely proportional to the variables of professional exhaustion in nurse managers and care nurses, although the job satisfaction variables were all negative and there is an understanding that the higher the dependent variable, the lower the independent variable.

\section{DISCUSSION}

The studied population was predominantly female (94.3\%), a marked characteristic among Brazilian nurses in primary, secondary and/or tertiary health services, as shown in several studies ${ }^{(2,17-18)}$. In the literature, there is no strong scientific evidence on the relationship between the gender variable and Burnout ${ }^{(2,7,19)}$.

Most participants were in the 50-59 age group (38.5\%), with an average of 45.2 years $(\mathrm{SD} \pm 9.8)$, data similar to studies conducted in $\mathrm{Brazil}^{(2)}$ and abroad ${ }^{(20-21)}$. According to evidence in the literature, the level of burnout is higher among younger workers than among those over 30 or 40 years old ${ }^{(22)}$. However, these results contradict a systematic literature review, according to which younger nurses are less likely to develop Burnout, as they are more motivated, while older professionals feel more exhausted as a result of performing the same routine tasks for years with stress and work overload ${ }^{(5)}$.

Younger nurses have more problems related to career instability, unmet expectations and salary, as well as a greater predisposition to depersonalization ${ }^{(2,19,23)}$. However, depersonalization is a strategy to manage the professional's inexperience, combined with a significant relationship with the workplace in $\mathrm{PHC}^{(7,24)}$. In a study conducted in Canada, the latent profile was analyzed to identify professional burnout ${ }^{(25)}$ based on longitudinal research and hypothesis testing centered on the person and the work environment. It was identified that skepticism or cynicism was closer to the negative profile of burnout in relation to the social context and satisfaction than high exhaustion and, therefore, needs more attention in the evaluation of professional exhaustion, together with inefficiency.

Regarding marital status, $59 \%$ of participants were married. In the literature, this variable is related to emotional exhaustion, professional exhaustion and Burnout syndrome in different ways. A study reveals that married nurses are affected by greater emotional exhaustion, but have higher levels of personal fulfillment and quality of $\mathrm{life}^{(7)}$. On the 
contrary, other investigations indicate that single individuals, especially men, are more prone to professional exhaustion and have higher levels of burnout than divorced people $\mathrm{e}^{(2,22,26)}$. However, single persons experience less emotional exhaustion, since in general, they are exempt from family demands $s^{(5)}$. In another study, data are inconsistent when relating marital status to professional exhaustion ${ }^{(24)}$.

The prevailing working time specifically in $\mathrm{PHC}$ was in the range of five to nine years (27.9\%), followed by 25 years or more $(21.3 \%)$. In a systematic literature review study ${ }^{(5)}$, professional experience emerged as an aspect that increases emotional exhaustion and decreases professional achievement.

A variable that differs from other investigations is the type of work contract, as nurses working in PHC in the city of Ribeirão Preto are mostly civil servants (86.1\%). The type of employment relationship and the formal employment contract (CLT) have important repercussions on the structuring of risks to workers' health with regard to common mental disorders and the quality of services provided ${ }^{(18)}$.

Studies show that the psychosocial environment of PHC is unfavorable to work given the high levels of perceived stress $^{(27)}$ and that primary care nurses have high levels of emotional exhaustion and are at a higher risk of developing burnout, anxiety and depression as a result of stress ${ }^{(28)}$.

Regarding the variable job satisfaction and professional exhaustion, studies indicate a negative relationship, that is, the more emotionally exhausted the worker feels, the more dissatisfied they will be, as observed in the results of this investigation. In addition, when there is a lack of adequate workplace facilities, the burnout level can increase by 1.8 times $^{(24)}$.

According to the Theory of Job Satisfaction ${ }^{(11)}$, IJS is considered a motivating variable for workers and is declining in the context of the performance of PHC nurses given the lack of opportunities and career growth, which has made individuals feel professionally dissatisfied ${ }^{(20,24)}$.

High levels of satisfaction are essential to make workers less prone to illness, more efficient, motivated and productive, in addition to favoring the permanence in the service and the successful implementation of health system reforms ${ }^{(5,29)}$.

In a Brazilian study, the health professionals investigated showed professional dissatisfaction together with the desire to abandon the profession. They often reported not finding a source of achievement at work and expressed feelings of discomfort, mental disorder diagnosed by a psychiatrist and emotional tension ${ }^{(2)}$, which can lead to Burnout syndrome.

People who experience Burnout syndrome are not simply exhausted or overwhelmed with the workload, but have lost a psychological connection to their work and feel unmotivated. Cynicism and aspects of inefficiency express the mismatch of the work-worker polarity and a crisis in expectations of work-based effectiveness ${ }^{(25)}$.

Professionals in management positions have less time to dedicate themselves to patients and consequently have lower levels of depersonalization. However, regardless of the position, PHC nurses have higher levels of depersonalization in relation to professionals from other health contexts, which, according to them, would be linked to repercussions of the individual's psychological demands at the psychosocial level ${ }^{(7)}$.

The results of this study corroborate other studies in which the occupational variables related to the organization, the process and the working conditions are strongly correlated with professional exhaustion and an environment with a negative organizational atmosphere ${ }^{(10,17,23)}$. Furthermore, the higher workload interferes with the process of work exhaustion associated with reduced perceptions of control over the environment, autonomy and organizational support ${ }^{(30)}$.

Thus, stressful conditions are inserted in the work organization and in workers' dissatisfaction for not reaching their values and opportunities, both for nurse managers and care nurses.

The limiting factors of this study were the scarcity of previous and recent studies on the role of nurses in the context of PHC, which made a broader discussion more difficult, in addition to the cross-sectional nature that made it impossible to establish causal relationships.

The results are relevant to statistical analysis, show the satisfaction and stress indicators and their correlation with the variables of professional exhaustion. Job satisfaction is inversely proportional to professional exhaustion, expressed in the strong link between IJS and professional exhaustion. Therefore, the decrease in job satisfaction can cause and intensify the chronicity of stress.

Thus, the results exposed in this investigation allow the expansion of scientific knowledge about the analyzed object and its translation into practice.

\section{CONCLUSION}

Nurses present indicators of job dissatisfaction regarding hierarchical relationships, compliance with legal rules, collective work agreements and the hiring of benefits; the physical work environment, which involves hygiene, healthiness and physical space; and factors intrinsic to work, such as career development opportunities. A level of stress in PHC professionals was identified in relation to factors such as lack of communication about organizational information, work overload, conflict of roles and impaired interpersonal communication. Burnout levels were moderate to high in relation to factors of emotional exhaustion, dehumanization and disappointment at work.

When relating the data obtained for nurse managers and care nurses, the difference between the dehumanization variables and IJS was significant. When correlating the study variables, dehumanization was significant with stress and IJS in the group of nurse managers, while in the group of care nurses, dehumanization occurred independently. Regardless of the position, only IJS was strongly correlated to all variables of professional exhaustion. Therefore, the association between organizational problems and working conditions hinders the work of this professional, who has proven to be essential for the proper functioning of the system.

The importance of developing studies that prioritize the search for strategies to create and/or change the current occupational health policies is emphasized, so they become more protective and proponent of preventive actions to avoid the chronicity of occupational stress of health workers. 
RESUMO

Objetivo: Correlacionar os indicadores de satisfação no trabalho, fatores de estresse ocupacional e de esgotamento profissional entre os enfermeiros gestores e assistencialistas da Atenção Primária à Saúde. Método: Estudo de campo, descritivo, de caráter exploratório realizado em 45 unidades da Atenção Primária à Saúde do Brasil. Na coleta de dados, foram utilizados os instrumentos: Questionário Sociodemográfico, Escala de Estresse no Trabalho, Escala de Caracterização de Burnout e o Questionário de Satisfação no Trabalho - S20/23. Resultados: Participaram 122 enfermeiros (47,5\% gestores e 62,5\% assistencialistas), 32\% apresentaram nível de estresse considerável, indicadores de exaustão emocional, desumanização e decepção no trabalho em níveis moderados a altos. O indicador satisfação com o ambiente físico de trabalho não apresentou significância com as variáveis do esgotamento profissional, mas a satisfação com relações hierárquicas e intrínsecas ao trabalho são fortemente correlacionadas. Conclusão: Há uma associação entre os problemas organizacionais e as condições de trabalho que dificultam o trabalho dos enfermeiros. Independente da função, a satisfação no trabalho é inversamente proporcional ao esgotamento profissional.

\section{DESCRITORES}

Enfermagem de Atenção Primária; Satisfação no Emprego; Estresse Psicológico; Esgotamento Profissional; Saúde do Trabalhador.

\section{RESUMEN}

Objetivo: Correlacionar los indicadores de satisfacción laboral, factores de estrés laboral y agotamiento profesional entre enfermeros gestores y enfermeros de cuidado en Atención Primaria de Salud. Método: Estudio de campo descriptivo, exploratorio, realizado en 45 unidades de Atención Primaria de Salud en Brasil. Para la recogida de datos se utilizaron los siguientes instrumentos: Cuestionario Sociodemográfico, Escala de Estrés Laboral, Escala de Caracterización del Burnout y Cuestionario de Satisfacción Laboral - S20/23.

Resultados: Participación de 122 enfermeros (47,5\% gestores; 62,5\% cuidados), 32\% presentaba niveles de estrés considerables, indicadores de agotamiento emocional, deshumanización y decepción en el trabajo en niveles moderados a altos. El indicador de satisfacción con el ambiente físico de trabajo no mostró significancia con las variables de agotamiento profesional, mientras que la satisfacción con la supervisión y la intrínseca del trabajo están fuertemente correlacionadas. Conclusión: Hay una asociación entre los problemas organizacionales y las condiciones laborales que dificultan el trabajo de los enfermeros. Independientemente del puesto, la satisfacción laboral es inversamente proporcional al agotamiento profesional.

\section{DESCRIPTORES}

Enfermería de Atención Primaria; Satisfacción en el Trabajo; Estrés Psicológico; Agotamiento Profesional; Salud Laboral.

\section{REFERENCES}

1. Brasil. Ministério da Saúde. Portaria n. 2.488, de 21 de outubro de 2011. Aprova a Política Nacional de Atenção Básica, estabelecendo a revisão de diretrizes e normas para a organização da Atenção Básica, para a Estratégia Saúde da Família e o Programa de Agentes Comunitários de Saúde [Internet]. Brasília; 2011 [citado 2018 jun. 17]. Disponível em: http://dab.saude.gov.br/portaldab/biblioteca. php?conteudo=legislacoes/esus

2. Silva SCPS, Nunes MAP, Santana VR, Reis FP, Machado NJ, Lima SO. Burnout syndrome in professionals of the primary healthcare network in Aracaju, Brazil. Ciênc Saúde Coletiva. 2015;20(10):3011-20. doi: 10.1590/1413-812320152010.19912014

3. Brasil. Ministério da Saúde. Portaria n. 648, de 28 de março de 2006. Aprova a Política Nacional de Atenção Básica, estabelecendo a revisão de diretrizes e normas para a organização da Atenção Básica para o Programa Saúde da Família e o Programa de Agentes Comunitários de Saúde [Internet]. Brasília; 2006 [citado 2018 jun. 17]. Disponível em: http://dab.saude.gov.br/docs/legislacao/ portaria_648_28_03_2006.pdf

4. Brasil. Ministério da Saúde. Portaria n 2.436, de 21 de setembro de 2017. Aprova a Política Nacional de Atenção Básica, estabelecendo a revisão de diretrizes para a organização da Atenção Básica, no âmbito do Sistema Único de Saúde (SUS) [Internet]. Brasília; 2017 [citado 2018 jun. 17]. Disponível em: https://bvsms.saude.gov.br/bvs/saudelegis/gm/2017/prt2436_22_09_2017.html

5. Gómez-Urquiza JL, Monsalve-Reyes CS, Luis-Costas CS, Fernández-Castillo R, Aguayo-Estremera R, Cañadas-de la Fuente GA, et al Factores de riesgo y niveles de burnout en enfermeiras de atención primaria: uma revisión sistemática. Aten Primaria. 2017;49(2):77-85. doi: https://doi.org/10.1016/j.aprim.2016.05.004

6. Toso BRGO, Filippon J, Giovanella L. Nurses' performance on primary care in the National Health Service in England. Rev Bras Enferm. 2016;69(1):169-177. doi: http://dx.doi.org/10.1590/0034-7167.2016690124i

7. Cañadas-De la Fuente GA, Vargas C, San Luis C, García I, Cañadas GR, De la Fuente E, et al. Risk factors and prevalence of burnout syndrome in the nursing profession. Int J Nurs Stud. 2015;52(1):240-9. doi: https://doi.org/10.1016/j.ijnurstu.2014.07.001

8. Garcia GPA, Marziale MHP. Indicators of burnout in Primary Health Care workers. Rev Bras Enferm [Internet]. 2018;71 Suppl 5:2334-42. [Thematic Issue: Mental Health] doi: http://dx.doi.org/10.1590/0034-7167-2017-0530

9. Viana VCA, Santos FPA, Nery AA; Oliveira, JS; Almeida, CLS et al. Nurses' working condition in family health strategy: integrative review. Rev Enferm UFPE [Internet]. 2016 [cited 2018 Jun 23];10(7):2696-707. Available from: https://periodicos.ufpe.br/revistas/ revistaenfermagem/article/view/11331/13030

10. Granero A, Blanch JM, Ochoa P. Labor conditions and the meanings of nursing work in Barcelona. Rev Latino Am Enfermagem. 2018; 26:e2947. doi: http://dx.doi.org/10.1590/1518-8345.2342.2947

11. Locke EA. What is job satisfaction? Organ Behav Hum Perform. 1969;4(4):309-36. doi: https://doi.org/10.1016/0030-5073(69)90013-0

12. Martinez MC, Paraguay AIBB. Satisfação e saúde no trabalho: aspectos conceituais e metodológicos. Cad Psicol Soc Trab. 2003;6:59-78. doi: https://doi.org/10.11606/issn.1981-0490.v6i0p59-78

13. Locke EA. The motivation sequence, the motivation hub and the motivation core. Organ Behav Hum Decis Process. 1991;50(2):288-99. doi: https://doi.org/10.1016/0749-5978(91)90023-M

14. Paschoal T, Tamayo A. Validação da Escala de Estresse no Trabalho. Estud Psicol (Natal). 2004;9(1):45-52. doi: http://dx.doi.org/10.1590/ S1413-294X2004000100006 
15. Tamayo MR, Tróccoli BT. Construção e validação fatorial da Escala de Caracterização do Burnout (ECB). Estud Psicol (Natal). 2009; 14(3):213-21. doi: http://dx.doi.org/10.1590/S1413-294X2009000300005

16. Carlotto MS, Câmara SG. Propriedades psicométricas do Questionário de Satisfação no Trabalho (S20/23). Psico-USF. 2008;13(2):203-10. doi: http://dx.doi.org/10.1590/S1413-82712008000200007

17. Campos ICM, Angélico AP, Oliveira MS, Oliveira DCR. Fatores sociodemográficos e ocupacionais associados à síndrome de Burnout em profissionais de Enfermagem. Psicol Reflex Crit [Internet]. 2015 [citado 2018 jun. 15];28(4):764-71. Disponível em: http://www.scielo.br/ pdf/prc/v28n4/0102-7972-prc-28-04-00764.pdf

18. Mattos AIS, Araújo TM, Almeida MMG. Interaction between demand-control and social support in the occurrence of common mental disorders. Rev Saúde Pública. 2017;51(48):1-9. doi: http://dx.doi.org/10.1590/s1518-8787.2017051006446

19. Marôco J, Marôco AL, Leite E, Bastos C, Vazão MJ, Campos J. Burnout em profissionais da saúde portugueses: uma análise a nível nacional. Acta Med Port [Internet]. 2016 [citado 2018 jun 23];29(1):24-30. Disponível em: https://www.actamedicaportuguesa.com/revista/index. php/amp/article/viewFile/6460/4534

20. Halcomb E, Ashley C. Australian primary health care nurses most and least satisfying aspects of work. J Clin Nurs. 2017;26(3-4):535-45. doi: https://doi.org/10.1111/jocn.13479

21. Munyewende P, Rispel LC, Chirwa T. Positive practice environments influence job satisfaction of primary health care clinic nursing managers in two South African provinces. Hum Resour Health [Internet]. 2014 [cited 2018 June 22];12(27):1-14. Available from: https:// www.ncbi.nlm.nih.gov/pmc/articles/PMC4024627/

22. Maslach C, Schaufeli WB, Leiter MP. Job burnout. Annu Rev Psychol. 2001;52:397-422. doi: https://doi.org/10.1146/annurev. psych.52.1.397

23. Maissiat GS, Lautert L, Pai DD, Tavares JP. Work context, job satisfaction and suffering in primary health care. Rev Gaucha Enferm [Internet]. 2015 [cited 2018 June 15];36(2):42-9. Available from: http://www.scielo.br/pdf/rgenf/v36n2/1983-1447-rgenf-36-02-00042.pdf

24. Amiri M, Khosravi A, Eghtesadi AR, Sadeghi Z, Abedi G, Ranjbar M, et al. Burnout and its influencing factors among Primary Health Care Providers in the North East of Iran. PLoS One. 2016;11(12):e0167648. doi: https://doi.org/10.1371/journal.pone.0167648

25. Leiter MP, Maslach C. Latent burnout profiles: a new approach to understanding the burnout experience. Burn Res. 2016;3(4):89-100. doi: https://doi.org/10.1016/j.burn.2016.09.001

26. Maslach C. Entendendo o Burnout. In: Rossi AM, Perrewé PL, Sauter SL, organizadores. Stress e qualidade de vida no trabalho: perspectivas atuais da saúde ocupacional. São Paulo: Atlas; 2005. p. 41-55.

27. García-Rodriguez A, Gutiérrez-Bedmara M, Bellón-Saameño JÁ, Muñoz-Bravo C, Navajas JFC. Entorno psicosocial y estrés en trabajadores sanitarios de la sanidad pública: diferencias entre atención primaria y hospitalaria. Aten Primaria. 2015;47(6):359-66. doi: https://doi. org/10.1016/j.aprim.2014.09.003

28. Duhoux A, Menear M, Charron M, Lavoie-Tremblay M, Alderson M. Interventions to promote or improve the mental health of primary care nurses: a systematic review. J Nurs Manag. 2017;25(8):597-607. doi: https://doi.org/10.1111/jonm.12511

29. La Cruz SP, Abellán MV. Professional burnout, stress and job satisfaction of nursing staff at a university hospital. Rev Latino Am Enfermagem. 2015;23(3):543-52. doi: 10.1590/0104-1169.0284.2586

30. Lorenz VR, Guirardello EB. The environment of professional practice and Burnout in nurses in primary healthcare. Rev Latino Am Enfermagem. 2014;22(6):926-33. doi: 10.1590/0104-1169.0011.2497 